\title{
The Translation of Arabic Collocations into English: Dictionary-based vs. Dictionary-free Measured Knowledge
}

\author{
Dinha T. Gorgis (Jadara University)/Aladdin Al-Kharabsheh (Hashemite University)
}

\begin{abstract}
This paper compares the output of two translation tasks. In an attempt to find out the extent to which students of translation can translate Arabic contextualized collocations into English properly, two conflicting views about carrying out a translation task are tested. The first holds that avoiding the use of a dictionary in test sessions, though not in translation classes, would save time and yield better translation products, whereas the second contends that recourse to a dictionary is unavoidable at any translation task, including tests. The two opposing views have their corollary in a similar dispute which has already been settled in favour of the mental lexicon rather than the dictionary (cf. Rangelova/Echeandia 2003). The results of this study defeat the first claim and run counter to Rangelova/Echeandia's findings, though obtained from qualitatively a different test setting.
\end{abstract}

\section{$1 \quad$ Introduction}

Collocations, roughly defined as expressions exhibiting words in company or, better put, as conventional, recurrent and non-idiomatic expressions consisting of mainly two lexical items, e.g. constant/sharp (but not continuous/strong) pain, have received considerable attention over the last few decades. Although definitions proliferate in the literature, often quoting Firth (1951) directly or indirectly, collocations remain "notoriously difficult to define" (Leśniewska 2006: 95; see also Poulsen 2005; Martyńska 2004: 5). Despite our awareness of the difficulty of both their definition and accommodation in linguistic theory, collocations, including grammatical, are taken here for granted because of the commonly held view of habitual cooccurrence of lexical items regardless of adjacency or proximity between one item and another. Recent empirical research is said to have "defied difficulties and criticism and sparked renewed interest in a number of areas ranging from computational and corpus linguistics to lexicography, language pedagogy, and [...] translation studies" (Baroni/ Bernardini 2003: 1). Thus excellent dictionaries such as the BBI by Benson, Benson and Ilson (1986/1997), Lea's (2002) Oxford Collocations Dictionary for students of English, LTP Dictionary of Selected Collocations by Hill/Lewis (1997), Sinclair's (2001) Collins Cobuild English Language Dictionary, Hafiz (2004) Arabic Collocations Dictionary, inter alia, and two complementary textbooks on collocations in use, viz. intermediate and advanced (McCarthy/O'Dell 2005 and O'dell/McCarthy 2008) have been produced recently. And, as planned, we expect to see more bilingual dictionaries, such as Abu-Ssaydeh (forthcoming) on Arabic-English collocations, than what has so far been made available, viz. Ghazala (2007), Wang (1988) and Bogatz (1997) on English-Arabic, Chinese-English and German-English collocations, respectively.

A cursory look at the partial list of references we have come across and/or the bibliography compiled by Cowie/Howarth (1996) should be clear evidence of world-wide interest in the study of collocations, English collocations in particular. Obviously, this interest has mainly 
grown out of the feeling that learners of English as a foreign or second language, including advanced learners and professional translators, continuously stumble over which words go hand in hand with which appropriately (cf. Taiwo 2004; Koosha/Jafarpour 2006; Hüttner 2005; Walsh 2005; Millar 2005; Martyńska 2004; Lindquist 2003; Wray 2000; Macedo 2000; Bahns 1993, inter alia). Research in especially applied linguistics, translation included, has focused on several themes, on top of which stands the notion of competence. Testing collocational knowledge, both monolingually and/or interlingually, is attested in the literature (cf. Jaén, 2007; Brashi, 2005; Mahmoud 2005; Farghal/Obiedat 1995; Farghal/Shakir 1992f., inter alia). The majority of tests made available are elicitation tests, both productive and receptive, whose overall purpose is to measure the degree of competence in the learner's linguistic repertoire and hence the forwarding of suggestions and/or teaching techniques in an attempt to remedy the problems learners and trainee translators face (cf. Al-Sibai 2009; Mahmoud 2005; Sarikaş 2006, among others). As such, error analysis has become fashionable but, additionally, a number of pedagogy researchers have focused on the strategies learners adopt while translating from and into English or consulting, as well as evaluating, general-purpose dictionaries in the absence of specialized collocational dictionaries such as the ones mentioned above (see, e.g. Vrbinc 2005; Hafiz 2002; 2004).

The present paper follows suit, but the objective is totally different. By measuring the collocational knowledge of undergraduate students, the tests conducted in this paper are used as a means to a different end (cf. Bahumaid 2006). The results of the tests are taken as an index to the reliability of either the general-purpose dictionary use or the mental lexicon in translating Arabic collocations into English. In other words, we intend to measure dictionarybased vs. dictionary-free collocational knowledge of translation trainees. As such, section two of this paper outlines the issue at stake, i.e. the rationale behind our attempt and hence the hypothesis. Section three reports on the subjects being experimented and the design exploited. Section four introduces the test material along with few remarks on reasons behind the authors' choice. While section five displays the results obtained and discusses their significance, section six concludes the paper with a number of suggestions. The Appendix attached to the paper is meant to show the reader an optimal translation of the 30 Arabic sentences into English, irrespective of how close to Standard Arabic they are.

\section{The Issue at Stake: The Rationale}

It goes without saying that consulting specialized and/or bilingual dictionaries in training translation classes is as important as using one's mind in search of meaning. This is a widely held view among translation practitioners (cf. Abu-Ssaydeh 2007; Sánchez Ramos 2005; McKeon/Radev 2000; Hussein 1998). But when it comes to the question of whether or not using a dictionary in an examination relevant to previous training, conflicts between respective adherents may arise. This is exactly what the present paper addresses in relation to the translation of Arabic collocations into English. The rationale behind this piece of research was initially motivated by two controversial views held by the two authors. The first, advocated by the first author, claims that more efficient translations can be done without the use of a dictionary in test sessions. The claim is based on the belief that the students who have already had access to general-purpose dictionaries during training must be linguistically and psychologically ready to take an examination without using a dictionary; for it is, above all, assumed that they have possessed a considerable amount of vocabulary during their past 15 years of learning English as a foreign language. The claim derives its strength from higher grades scored by a number of $3^{\text {rd }}$-year undergraduates taking an Arabic-English translation course with the first author who, in contradistinction to the rest of their classmates, opted for not using the dictionary. It should be noted, however, that those who chose to translate on a dictionary-free basis were mostly top students. The second, subscribed by the second author, 
claims that recourse to a dictionary is unavoidable at any stage of training undergraduates, including examinations.

The underlying assumption here is that, according to the dictionary-based view, training translators will skim the readily accessible dictionary entries in search for the most adequate and reliable equivalents. The dictionary-free view contends that trainees will skim translational correspondences, including lexical relations as stored in their mental lexicon, in no time. Not only this, but holds that "the human word-store contains far, far more information about each lexical entry" (Rangelova/Echeandia 2003). Indeed, this is bound to present conflicting entailments. The former, for instance, seems to entail the likelihood, on the part of an equivalent-finder, to resort to generally the first given dictionary entry, thus a predilection to venture down the path of literal translation could be tenable here. By contrast, the latter, which advocates a dictionary-free treatment of equivalence, seems to entail the ability to skim and access the closest options, if already stored, in the mental lexicon; that is, the skimming process, though requiring more cognitive processing on the part of trainees, but less sight tracking, is more likely to result in a fewer selection of senses for the required lexical item and hence the choice of a functional equivalent that emerges in a relatively shorter time span. In the first author's experience, the dictionary-based selection freedom is, accordingly, time-consuming because entry meanings in the general dictionaries made available to novice translators in the class are not listed to well-defined criteria and objectives and hence the indeterminacy and indecisiveness on the part of the proper sense finder. That a dictionary-free task saves time is already implicitly acknowledged in James Cook University's document on Policy and Procedures regarding "Student Access to a Dictionary During an Examination"1.

The manual states the following: "Candidates using a bilingual English translation dictionary are not permitted extra time to complete their examination." No wonder, it is reported that $70 \%$ of the translation instructors in Saudi Arabia universities do not allow their students to use dictionaries in class or test sessions (cf. Al-Jarf 2001). In the second author's relatively shorter experience, on the other hand, equal opportunities are offered to trainees and/or testees in an attempt to create a healthy "feel-free" class, not to mention the fact that it has been traditionally held that dictionaries are authoritative, better sources for finding delicate meanings and lexical associations than relying on intuition and stored knowledge in the mind. This view is by and large the norm on the current scene (cf. Ryu 2006; Maurer-Stroh 2004); dictionary use is more often than not recommended and encouraged.

Incidentally, these two conflicting views have already been tested by Rangelova/Echeandia (2003) who hypothesized that "dictionary entries are not representative of the way humans link words together in their minds" (2003: 2). Their sample subjects for the study, which included 16 dictionaries and a questionnaire on how learners use them, were 26 international students enrolled in the intermediate and advanced level ESL classes in the English Language program at the University of Albany, New York. The students came from a diversity of countries representing eight different languages. They concluded that dictionaries are limited in scope in comparison with the mental lexicon and, therefore, "tend to overlook the way lexical items are interconnected in semantic memory" (ibd.). In an attempt to find out preferences in employing the 16 dictionaries, their results showed that their subjects "chose the definitions that included examples of the systematic collocational patterns of words as "most helpful" over definitions that did not contain collocations" (2003: 4).

By extension, this paper purports to investigate the matter in an endeavour to settle the dispute between the present researchers and, as a by-product, to verify the dictionary/mental lexicon

\footnotetext{
${ }^{1}$ http://www.jcu.edu.au/policy/allitoz/JCUDEV_005335.html.
} 
results obtained by Rangelova/Echeandia. Our ultimate goal is, therefore, not the identification of translation errors and their classification, e.g. Hussein (1998); AlHamly/Farghal (2008); Shin 2007; Hemchua/Schmitt (2006); Li (2005); Kasuya (2000; 2008), inter alia. We neither intend to suggest remedies for the problems novice translators face, nor explore the strategies adopted by novice translators, e.g. Zughoul/Abdul-Fattah (2003). Equally so, it is neither designed to propose strategies for improving dictionary use (cf. Roberts 1992), nor meant to assess the utility of any available dictionary along the lines of, e.g. Abu-Ssaydeh (2007) or Rangelova/Echeandia (2003). Rather, it is intended to test the collocational knowledge of two groups of university undergraduates based on their translation output in order to answer one simple question: Should dictionaries be allowed in test sessions at the time learners have already had 15 years of exposure to English vocabulary?

\section{$3 \quad$ Population and Design of the Study}

To achieve the main objective of the study, two separate collocational tests were conducted on two different groups of four-year students majoring in English language and literature at the Hasehmite University, Jordan. All the 71 subjects tested had no previous formal training in translating collocations from Arabic into English or vice versa, but had already passed a general English-Arabic translation course in their third year. The first test, being dictionarybased, was conducted on a group comprising 31 students in 2005 whereas the second test, dictionary-free, on a group comprising 40 students in November 2008. Although it is widely held that $4^{\text {th }}$-year undergraduates represent relatively a homogenous society, the researchers intended to verify the claim by splitting the testees' performance in each test into three units according to the grades obtained in previous translation examinations. So for each level, viz. very good, good and average, we get two corresponding sub-groups, i.e. very good vs. very good, good vs. good and average vs. average. Such a one-to-one correspondence is not trivial; for it will enable us to draw conclusions in terms of the students' level of performance prior to coming up with the intended generalizations across the two major groups, viz., A \& B whose sub-groups are correspondingly labeled A1, A2 and A3 vs. B1, B2 and B3. In order to verify the above claim, we need to find out: (1) whether or not the grades obtained previously in translation examinations correlate with the performance of each sub-group in translating Arabic collocations into English; and (2) the extent to which students in each sub-group agree collectively on the required sense equivalent(s) and hence a legitimate comparison between corresponding sub-groups and the two major groups. Because the two tests were not part of an examination, the students were encouraged to do their best in the test. They were told that 1-5 marks would be given as a bonus depending on the quality of their performance. They had never been made aware that the test was run for experimental purposes, designed in such a way as to measure their knowledge of Arabic and/or English collocations or intended to see how well one group would use any bilingual or general-purpose monolingual dictionary and the other would only use their mental linguistic repertoire. So the two tests, each of which took one hour to finish, was quite serious and competitive.

\section{$4 \quad$ Test Material}

The researchers agreed on testing the translation potential of only three lexical items: two Arabic verbs and one verbal noun, each contextualized in ten different sentences. All the 30 sentences (see Appendix) were assumed to be common to the testees. The three lexical items, viz. /đaraba/ 'hit', /haşara/ 'enclose' and /taxfiif/ 'diluting', the general meanings of which are given here for convenience, were chosen on purpose. Because they are polysemous, i.e. display multiple senses, the range of collocability is expected to be wider and hence requiring a considerable search for the best collocating sense in a manual/electronic dictionary and, to a lesser degree, the mental lexicon. In fact, both Wehr (1994) and Baalbaki (1995) list over 100 
senses for the first item, over 40 for the second, and around 30 for the third, respectively. Since specialized dictionaries such as those mentioned in the introduction are not available in the University library, the members of group A were asked to feel free using any available dictionary in their search of the most convenient sense-relation equivalent. The majority in group A used Wehr's (1994) and Baalbaki's (1995) Arabic-English dictionaries, already criticized by Abu Ssaydeh (2007) for their inadequacy to cope with collocations, while very few used monolingual English paper and electronic dictionaries. In contrast, those of group B were asked to use their minds only. The total number of sentences translated by group A were 31 × $30=930$ and group B 40 × $30=1200$. This should not mean that we end up with $930+1200=2130$ English translations showing all sense relations for the three lexical items. Rather, we look forward to seeing the extent to which the translation of sub-groups and, ultimately, the two main groups get close to the optimal 30 translations provided by the two authors. So it is against the two authors' translation that the output of the subjects under study is assessed. Since both authors are professional translators and linguists, with a fairly longstanding experience in translating/interpreting and teaching translation for advanced learners, the said translations have not been referred to a third party for reliability validity.

It is to be noted, however, that the provision of 30 English collocations for 30 corresponding Arabic sentences is far from reality. Paraphrases are expected either way; for "one cannot assume that a concept expressed by way of collocation in one language will use a collocation in another language" (McKeon/Radev 2000: 12). Naturally, this would be too ideal; for whatever spatiotemporal constraints, among others, are imposed on collocational tests and/or whoever the tested populations are, variation in translating collocations is inevitable. Some readers might even cast doubts on words in company in the Arabic sentences as belonging to the domain of collocations, e.g. sentence 1 below, which is true if we go by one definition rather than the other made available in the literature. Since "there is no exhaustive and uniform definition or categorization of collocation" (Martyńska 2004: 5), it would be quite sufficient for the purpose of this paper to follow the Firthian's "words in company", a statement made over seven decades ago, while hoping to introduce fresh insights in a separate work.

\section{$5 \quad$ Results and Discussion}

In processing the figures we have obtained, we initially listed the number of sense equivalents given by students under each of the ten sentences selected for each of the three lexical items. For example, if ten students agreed on the sense of 'hit' for the Arabic verb /đaraba/, as shown in sentence 1 below, then we placed 'hit 10' under S1. If 5 students agreed on the sense of 'beat' for the same verb in sentence1, we placed 'beat 5' under S1. Having finished identifying and counting all the senses obtained for the first sentence, we moved to the senses of the second sentence and the rest in the same manner. As such, we ended up with a table that contains numbers S1-S10, representing the ten sentences for each of the three targeted lexical items, under each of which the number of occurrences for each sense appears. This should mean that the performance of each sub-group appears numerically in one single table. Thus the figures of six tables, viz. three for A1, A2 and A3 vs. three for B1, B2 and B3 are processed, presented and juxtaposed in such a fashion that the total figures in table 1 below represent a summary which will enable us to compare and contrast the six sub-groups and hence the two main groups.

Table 1, therefore, shows the real total number of sense equivalents given for each of the three lexical items. For example, sub-group A1 who used a dictionary, scored 57 senses for the verb /đaraba/ 'hit', whereas B1, a dictionary-free sub-group, scored 86 for the same verb. To reiterate, only 10 sense equivalents are assumed to be the optimum. It is crystal clear then how much variation is involved in the subjects' performance, especially for the verb /haşara/ 
which shows more complex sense relations than the other two lexical items. For example, sentence no. 1 of verb /đaraba/, viz.

1. /đaraba zaydun çumaran/

'Zayd hit Umar'

is given only three senses by A1 and B1, viz. 'hit', 'beat' and 'strike', whereas sentence 8, viz.

8. /đaraba 1-mudiiru biyadin min hadiid/

'The headmaster ran the school firmly'

is given 11 senses by $\mathrm{A} 1$ and 10 senses by $\mathrm{B} 1$. This difference in variation is naturally due to the degree of literalness and/or metaphoricity involved in a given lexical combination. Roughly, one may conclude that the less senses given for each lexical item by each subgroup, the closer to the optimal translations students are. The more, the worse, by definition. Yet the numerical differences as displayed in table 1 should not be considered as they stand because of the difference in the number of students in each sub-group and the two major groups, A \& B, of which they are sub-sets. Therefore, table 2 below, is meant to demonstrate averages.

\begin{tabular}{|c|c|c|c|c|}
\hline (Sub)group & No. of students & $\begin{array}{c}\text { No. of senses: } \\
\text { đaraba (Vb) }\end{array}$ & $\begin{array}{c}\text { No. of senses: } \\
\text { haşara (Vb) }\end{array}$ & $\begin{array}{c}\text { No. of senses: } \\
\text { taxfiif (VN) }\end{array}$ \\
\hline A1 & 11 & 57 & 71 & 50 \\
\hline B1 & 18 & 86 & 96 & 86 \\
\hline A2 & 10 & 54 & 67 & 52 \\
\hline B2 & 11 & 57 & 69 & 62 \\
\hline A3 & 10 & 54 & 77 & 56 \\
\hline B3 & 11 & 63 & 79 & 66 \\
\hline A & 31 & 65 & 215 & 158 \\
\hline B & 40 & 206 & 244 & 214 \\
\hline
\end{tabular}

Table 1: Total no. of senses given by students to each lexical item

The method of reducing figures simply goes like this: each of the first six rows will show the total number of senses given to the three lexical items followed by an average of the three items per one student in the sub-group. The last two rows represent the total number of senses given for the three items by groups $\mathrm{A}$ and $\mathrm{B}$ followed by their average per one student in either group. The average in each set of rows is thus obtained by dividing the number of senses by the number of students in each (sub)group. 


\begin{tabular}{|c|c|c|c|}
\hline (Sub)group & No. of students & $\begin{array}{c}\text { Total no. of senses } \\
\text { for all 3 items }\end{array}$ & $\begin{array}{c}\text { Average of all 3 } \\
\text { items per student }\end{array}$ \\
\hline A1 & 11 & 178 & 16.18 \\
\hline B1 & 18 & 268 & 14.88 \\
\hline A2 & 10 & 173 & 17.3 \\
\hline B2 & 11 & 188 & 17.09 \\
\hline A3 & 10 & 187 & 18.7 \\
\hline B3 & 11 & 208 & 18.9 \\
\hline A & 31 & 538 & 17.393 \\
\hline B & 40 & 664 & 16.956 \\
\hline
\end{tabular}

Table 2: Total no. of senses given to three lexical items and their average per one single student in each (sub)group

The differences in the total number as shown in table 2 might be intriguing at a first glance. In fact, it is the average that concerns us more. When this average is divided by three (see table 3), we can easily correlate one single item, on average, per one student in each (sub)group. However, the average figures, as they stand now in table 2, may tell the reader something, namely, that dictionary-free students in B1, i.e. top students, are considerably better than those using a dictionary in A1, again top students, because they selected less sense relations. This is not necessarily true as we shall see later. What might also seem amazing is that the other corresponding sub-groups are almost the same, i.e. it is all the same, whether students use a dictionary or not. table 3 below, which is a mini picture of table 2 , shows some surface generalization in terms of a lexical average per an individual in a (sub)group. The reason why we reduce the average as shown in table 2 to an average per just one lexical item as given in table 3 is that we intend to compare the reduced figures with the ultimate average, viz. an average of the most acceptable English collocational/translational equivalents regardless of how many corresponding senses (sub)groups had selected.

\begin{tabular}{|c|c|c|}
\hline (Sub)group & No. of students & $\begin{array}{c}\text { Average of one item per } \\
\text { student }\end{array}$ \\
\hline A1 & 11 & 5.393 \\
\hline B1 & 18 & 4.96 \\
\hline A2 & 10 & 5.766 \\
\hline B2 & 11 & 5.69 \\
\hline A3 & 10 & 6.233 \\
\hline B3 & 11 & 6.303 \\
\hline A & 31 & 5.784 \\
\hline B & 40 & 5.533 \\
\hline
\end{tabular}

Table 3: Average of senses given by one student to one lexical item

Although the figures shown in tables 1,2 and 3 clearly show slight differences between (sub)groups, they may be statistically significant. Even though, they would tell us just one thing: that the performance of dictionary-free subjects is slightly better because they have selected fewer senses for the three lexical items than those who used a dictionary. The implication of this result is two-fold: (1) that the students in group A are more distracted in their search for the required senses than group B because of the multiplicity of senses made available in the dictionary; and (2) that the students' linguistic repertoire in group B is so 
limited that they were unable to provide as many senses as those given by group A. Yet when it comes to the question of which (sub)group is closer to the 30 optimal translations corresponding to the 30 Arabic sentences, we shall get a completely different picture. Table 4 below summarizes the results:

\begin{tabular}{|c|c|c|c|}
\hline (Sub)group & No. of students & $\begin{array}{c}\text { Total no. of appropriate } \\
\text { collocations }\end{array}$ & $\begin{array}{c}\text { Average of appropriate } \\
\text { collocations per one } \\
\text { student for a single item }\end{array}$ \\
\hline A1 & 11 & 100 & 3.0 \\
\hline B1 & 18 & 77 & 1.425 \\
\hline A2 & 10 & 92 & 3.06 \\
\hline B2 & 11 & 73 & 2.212 \\
\hline A3 & 10 & 71 & 2.366 \\
\hline B3 & 11 & 39 & 1.181 \\
\hline A & 31 & 263 & 2.827 \\
\hline B & 40 & 189 & 1.575 \\
\hline
\end{tabular}

Table 4: Total no. of appropriate collocations given by (sub)groups and average of appropriate collocations for a single lexical item given by one student

Table 4 should enable us to draw conclusions on the basis of comparing averages of selected items per one student in the (sub)group, irrespective of approximation to the required sense by each of the 30 sentences (as shown in table 3), with those of table 4, viz. averages of selected items per one student in the (sub)group in regard to how close the students were to the optimal sense relations. To draw a simple comparison more lucidly, an average student from A1 sub-group, for example, can select 3.0 appropriate senses from the dictionary in an attempt to translate 10 collocations for a single lexical item on average, whereas an average student from group B1 can retrieve from memory only 1.425. Without carrying out any statistical test, it is crystal clear that the performance of subjects in B1 is doubly poor. To reiterate, the students in B1, categorized as top, have just been judged tentatively that they seem to be slightly better than those in A1, again top, because they selected fewer senses on average and hence assumed to be better guided by their linguistic repertoire, i.e., mental lexicon. But selecting fewer senses is by no means an indicator of better proficiency; for if we reversed the two settings, group A might have chosen fewer senses in the absence of a dictionary. The same argument, however, applies to the rest of the sub-groups, a gloomy picture indeed. Yet it remains to say that he results are suggestive rather than conclusive because our sample is so small and, perhaps, our tested examples are not part of an examination. As such, novice translators, including our university students, are not to be blamed for their poor performance. Perhaps instructors, who often complain about their students' poor achievements in training courses, are held responsible for quality. We shall leave justifications in the background!

\section{Conclusion}

The two authors set out to resolve a disputed issue between them, viz. whether the translation product of a group of $4^{\text {th }}$ year students using a general-purpose dictionary, whether bilingual or monolingual, is any better than those using only their minds, i.e. the mental lexicon. These two conflicting views have already been tested by Rangelova/Echeandia (2003) who hypothesized that "dictionary entries are not representative of the way humans link words together in their minds" (2001:2). Although the dictionary-based and the dictionary-free views are mainly linked with test sessions in our case, the two authors decided to verify the 
two claims by testing two groups of students far from the atmosphere of final examinations. This is why the translation of Arabic collocations into English was the only area to be tested. Other reasons had to do with ease of checking students' output against the authors' optimal translations, the relative ease of processing the figures obtained and straightforward comparison between (sub)groups.

Three Arabic lexical items, each of which contextualized in ten sentences which exhibited ten different collocations or sense relations, were given to two groups of $4^{\text {th }}$ year students, viz. A $\&$ B, for translation into English. The former included 31 subjects, assigned the task of using any general-purpose bilingual or monolingual dictionary, and the latter 40 subjects, assigned the task of using their minds only. The translation product of each group was split into three categories, viz. A1, A2 and A3 vs. B1, B2 and B3, according to the grades they had obtained in previous examinations to ensure fair comparisons across (sub)groups in terms of a convenient level of competence. Thus, we could safely talk about top, intermediate and average students. The resulting figures of (sub)group translations were tabulated according to the number of sense equivalents given to each of the 30 sentences. Having processed the first set of figures, it was found out that dictionary-free subjects are tentatively slightly better because they used fewer senses, on average, than the dictionary-based subjects. Yet on a closer inspection, the figures calculated on the basis of which (sub)group approximated the optimal translation equivalents revealed that the dictionary-free subjects are doubly poor. Although the results are disappointing on both sides, since deviation from the optimal translation as shown in the Appendix is enormous, the dictionary-based subjects are far better, a finding that runs counter to the first author's speculation, on the one hand, and to Rangelova/Echeandia's results, on the other hand.

Better results could have been obtained were the students involved in conscious-raising activities before the tests had taken place and/or instructed to use specialized dictionaries as those mentioned at the outset of this paper. We, therefore, believe that our tested students were mainly engaged in search of meaning and meanwhile preoccupied with producing correct syntax and spelling rather than looking for collocation or any sense relation equivalents. This should not mean that we expected them to give us 30 English collocations for 30 Arabic ones. At the time we doubted that the term 'collocation' had ever come across their minds, a one-to-one collocational correspondence was not our ultimate objective because we are fully aware that collocations in any two languages do not necessarily match. In fact, priority was given to testing their knowledge of Arabic collocations in the first place, which is evidently poor. For this reason, we were equally satisfied with their closest English translations of sense relations to those provided by the two authors.

\section{References}

Abu-Ssaydeh, Abdul-Fattah (2007): "Collocations and the Arabic-English dictionary. Ideas for better dictionaries". International Journal of Arabic-English Studies (IJAES) 8: 69-90.

Abu-Ssaydeh, Abdul-Fattah (forthcoming): An Arabic-English bilingual collocational dictionary.

Aitchison, Jean (1994): Words in the mind. An introduction to the mental lexicon. Oxford.

Al-Hamly, Mashael/Farghal, Mohammed (2008): "Collocations and colligations in EFL writing. An empirical study". Language and Linguistics 21: 121-128.

Al-Jarf, Reima Saad (2001): "Electronic dictionaries in translation classrooms in Saudi Arabia". Linguistica Communicatio 10: 127-134.

Al-Sibai, Dina (2009): Testing Saudi English collocational competence and its development. King Saud University. http://docs.ksu.edu.sa/PDF/Articles06/Article060208.pdf (accessed January 14, 2009).

Baalbaki, Rohi (1995): Al-Mawrid. A modern Arabic-English dictionary. $7^{\text {th }}$ edn. Beirut. 
Bahns, Jens (1993): "Lexical collocation. A contrastive view". ELT Journal 47/1: 56-63.

Bahumaid, Shawqi (2006): "Collocation in English-Arabic translation". Babel 52/2: 133-152.

Baroni, Marco/Bernardini, Silvia (2003): "A preliminary analysis of collocational differences in monolingual comparable corpora". In: Archer, Dawn/Rayson, Paul/Wilson, Andrew/ McEnery, Tony (eds.): Proceedings of the Corpus Linguistics 2003 conference. UCREL technical paper number 16. Lancaster: 82-91.

Benson, Morton/Benson, Evely/Ilson, Robert (1986/1997): The BBI combinatory dictionary of English. A guide to word combinations. Revised Edn. Amsterdam/Philadelphia.

Bogatz, Horst (1997): The Advanced Reader's Collocation Searcher (ARCS). http://www.geocities.com/athens/acropolis/7033/.

Brashi, Abbas S. (2005): Arabic collocations. Implications for translation. Ph.D. Thesis. University of Western Sydney.

Cowie, Anthony P./Howarth, Peter (1996): "Phraseology. A select bibliography". International Journal of Lexicography 9/1: 38-51.

Farghal, Mohammed/Shakir, Abdullah (1992f.): "Collocations as an Index of L2 competence in Arabic-English simultaneous interpreting and translation". FIT-newsletter XI/3: 227245.

Farghal, Mohammed/Obiedat, Hussein (1995): "Collocations. A neglected variable in EFL". International Review of Applied Linguistics in Language Teaching (IRAL) 33/4: 315-331.

Firth, John Rupert (1951): "Modes of meaning". In: id. (ed.) (1957): Papers in linguistics. Oxford.

Ghazala, Hasan (2007): Dar El-ilm's dictionary of collocations. English-Arabic. Beirut.

Hafiz, Al-Tahir Abd-Elsalam (2002): "Throw a party with collocations. The need for an Arabic combinatory dictionary". International Journal of Arabic-English Studies (IJAES) 3/1-2: 1-15.

Hafiz, Al-Tahir Abd-Elsalam (2004): Al-Hafiz Arabic Collocations Dictionary. Beirut.

Hemchua, Saengchan/Schmitt Norbert (2006): "An analysis of lexical errors in the English compositions of Thai learners". Prospect 21/3: 2-24.

Hill, Jimmie/Lewis, Michael (eds.) (1997): LTP Dictionary of Selected Collocations. Hove.

Hussein, Riyad F. (1998): "Collocations revisited". Language \& Translation (J. of King Saud Univ.) 10: 39-47.

Hüttner, Julia (2005): "Formulaic language and genre analysis. The case of student academic papers". Views. Vienna English Working Papers 14/1: 3-20.

Kasuya, Michiko (2000): Focusing on lexis in English classrooms in Japan. Analysis of textbook exercises and proposals for conscious-raising activities. M.A. Dissertation. University of Birmingham, UK.

Kasuya, Michiko (2008): "Teaching collocation in Japanese classrooms". http://www.cels.bham.ac.uk/resources/essays/Kasuya_Lexis_MichikoKasuya_.pdf (accessed 22/08/2008).

Koosha, Mansour/Jafarpour, Ali Akbar (2006): "Data-driven learning and teaching collocation of prepositions. The case of Iranian EFL adult Learners". Asian EFL Journal 8/8: 192-209.

Lea, Diana (ed.) (2002): Oxford Collocations for students of English. Oxford.

Leśniewska, Justyna (2006): "Collocations and second language use". Studia Linguistica 123: 95-105.

Li, Chia-Chuan (2005): A study of collocational error types in ESL/EFL college learners' writing. M.A. Thesis. Ming Chuan University.

Macedo, Alan R. (2000): "Lexis". http://www.cels.bham.ac.uk/resources/essays/Macedo3.pdf (accessed January 15, 2009). 
Mahmoud, Abdulmoneim (2005): "Collocation errors made by Arab learners of English". Asian EFL Journal. http://www.asian-efl-journal.com/pta_August_05_ma.php (accessed September 11, 2008).

Martyńska, Malgorzata (2004): "Do English language learners know collocations?" Investigationes Linguisticae XI: 1-12.

Maurer-Stroh, Philippa (2004): Towards a bilingual adjective-noun collocation dictionary of English and German. Ph.D. Dissertation. University of Klagenfurt. http://ubdocs.uniklu.ac.at/open/hssvoll/AC04445625.pdf (accessed August 18, 2008).

McCarthy, Michael/O'Dell, Felicity (2005): Collocations in use. Intermediate. Cambridge.

McKeon, Kathleen R./Radev, Dragomir R. (2000): "Collocations". In: Dale, Robert/Moisl, Hermann/Somers, Harold (eds.): A handbook of natural language processing. New York: 507-524.

Millar, Neil (2005): "The processing demands on non-native-like learner collocations on native speakers". Manuscript. Lancaster University. www.lancs.ac.uk/postgrad/millarn/Files/Background\%20to\%20study.pdf.

Moreno Jaén, María (2007): "A corpus-driven design of a test for assessing the ESL collocational competence of university students". International Journal of English Studies (IJES) 7/2: 127-147.

O'Dell, Felicity/McCarthy, Michael (2008): Collocations in Use. Advanced. Cambridge.

Poulsen, Sonja (2005): Collocations as a language resource. A functional and cognitive study in English phraseology. Ph.D. Dissertation. University of Southern Denmark.

Rangelova, Krassimira/de Echeandia, Diane (2003): "Book dictionaries and the mental lexicon. Cognitive strategies in processing lexical information". In: Koksal, Dincay (ed.): The Third International ELT Research Conference 'Languages for Life'. 22-24 May 2003. Çanakkale, Turkey. yadem.comu.edu.tr/3rdELTKonf/spkr_krassimira_rangelova.htm (accessed 15/08/2008).

Sarikaş, Ferah (2006): "Problems in translating collocations". Elektronik Sosyal Bilimler Dergisi 17: 33-40. http://www.e-sosder.com/dergi/1733-40.pdf (accessed August 11, 2008).

Sharoff, Serge/Babych, Bogdan/Hartley, Anthony (2006): "Using comparable corpora to solve problems difficult for human translation". Proceedings of the COLING/ACL 2006 Main Conference Poster Sessions: 739-746.

Shin, Dongkwang (2007): "What collocations would be unpredictable for Korean EFL learners?" Korean Journal of Applied Linguistics 23/2: 83-98.

Sinclair, John M. (2001): Collins Cobuild English Language Dictionary. $3^{\text {rd }}$ edn. London.

Taiwo, Rotimi (2004): "Helping ESL learners to minimize collocational errors". The Internet TESL Journal X/4: 1-5. http://iteslj.org/Techniques/Taiwo-Collocation.html (accessed July 15, 2008).

Vrbinc, Marjeta (2005): "Native speakers of Slovene and their translation of collocations from Slovene into English. A Slovene-English empirical study". Erfurt Electronic Studies in English (EESE) 8: 1-17.

Walsh, Matthew (2005): "Collocation and the learner of English". http://www.cels.bham.ac.uk/resources/essays/WalshLexis.pdf (accessed 20/08/2008).

Wang, Wenchang (1988): A Dictionary of English Collocations (English-Chinese). Nanjiang.

Wray, Alison (2000): "Formulaic sequences in second language teaching. Principle and practice". Applied Linguistics 21/4: 463-489.

Zughoul, Muhammad Raji/Abdul-Fattah, Hussein (2003): "Translational collocational strategies of Arab learners of English. A study in lexical semantics". Babel 49/1: 59-81. 


\section{Appendix: The English Translation of 30 Arabic Sentences}

\begin{tabular}{|c|c|}
\hline 1. Zaid hit Umar & | ا. ضرب زيد عمرا \\
\hline 2. The King minted the currency of his country. & Y. ضرب الملك عملة بلاده \\
\hline 3. He rejected his argument & "r. ضرب بكلامه عرض الحائط \\
\hline 4. A hurricane struck Asia region & ع. ضرب إعصار منطقة آسيا \\
\hline 5. The teacher offered many proverbs on justice & العدل ضرب المعلم أمثالا عدة في \\
\hline 6. The teacher provided supporting examples & آ. ضرب المعلم أمثلة توضيحية \\
\hline $\begin{array}{l}\text { 7. The teacher discussed the grammatical 'object' from } \\
\text { various perspectives }\end{array}$ & باب المفعوب النحوب ضروبا شتى في \\
\hline $\begin{array}{l}\text { 8. The headmaster ran the school firmly (or exercised a } \\
\text { tight grip) }\end{array}$ & 1. ضرب المدير بيد من حديد \\
\hline 9. Ibn Battuta roamed the world for years & 9نينا طو ال إبن بطوطة في الأرض \\
\hline $\begin{array}{l}\text { 10. The boy turned pale out of fear (i.e. he was scared to } \\
\text { death) }\end{array}$ & الصفرة خوفا الصبي لونه إلى الى \\
\hline
\end{tabular}

\begin{tabular}{|c|c|}
\hline 1. Zaid locked up his brother in the room & I. حصر زيد أخاه في الغرفة \\
\hline 2. The Kingdom conducted a census & Y. حصرت المملكة عدد سكانها \\
\hline $\begin{array}{l}\text { 3. The teacher scolded him so he couldn't utter a } \\
\text { word }\end{array}$ & "ا. و بخه المعلم فحصر أنفاسـا \\
\hline 4. He inserted his name between $\mathrm{X}$ and $\mathrm{Y}$ & ع. حصر أسمها بين السين و الصـاد \\
\hline 5. He bracketed the symbol & ○. حصر الرمز بين قوسين \\
\hline $\begin{array}{l}\text { 6. The teacher assembled the prepositions in one } \\
\text { poetic line }\end{array}$ & ش. حصر المعلم حروف الجر في بيت \\
\hline 7. The set of questions was restricted to three only & V. حُصر عدد الأسئلة بثلاثثة فقط \\
\hline $\begin{array}{l}\text { 8. He narrowed down his key word search to only } \\
\text { one }\end{array}$ & ^. حصر بحثُه في كلمة دالة واحدة \\
\hline 9. The pupil retained his urine during the exam & 9. حصر التلميذ بوله اثناء الامتحان \\
\hline 10. Only the poor were legible to rationing & • 1. حُصر التموين بالفقر اء \\
\hline
\end{tabular}




\begin{tabular}{|c|c|}
\hline 1. Canada has eased off immigration laws & 1. عملت كندا على تخفيف قو انين الهجرة \\
\hline 2. I asked the barber to trim my hair this time & المرة طلبت من الحلاق تخفيف شعري هذه \\
\hline $\begin{array}{l}\text { 3. It is the chemist who normally dilutes } \\
\text { thickened (concentrated) liquids }\end{array}$ & عادة يقوم الكيميائي بنخفيف المحاليل المكثفة \\
\hline $\begin{array}{l}\text { 4. Drivers are often reminded of slowing down } \\
\text { (reducing speed) at cross-roads }\end{array}$ & 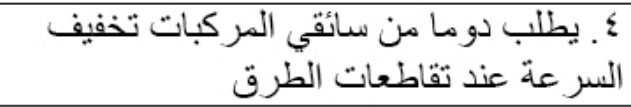 \\
\hline $\begin{array}{l}\text { 5. Doctors often advise the elderly to cut down } \\
\text { on (limit) their alcoholic drinks }\end{array}$ & الإدمان على الأطباء المسنين بتخفيف درجة المبنة \\
\hline $\begin{array}{l}\text { 6. The conference calls for reducing (easing off) } \\
\text { tension in the Middle East }\end{array}$ & في الثرعو المؤتثر إلى تخفيف حدة الصر اع \\
\hline 7. The doctor asked me to drop off (lose) weight & V. طلب مني الطبيب تخفيف وزني \\
\hline 8. Leukemia might result in blood thinning & ^ـ قد يؤدي مرض اللوكيميا إلى تخفيف الدم \\
\hline $\begin{array}{l}\text { 9. Governments do their best to relieve the poor } \\
\text { of their heavy living burden }\end{array}$ & الفقر اء المعاشية الحكو البائسة جاهدة إلى تخفيف أعباء \\
\hline $\begin{array}{l}\text { 10. Relatives pay visits to patients in hospitals to } \\
\text { soothe their pains }\end{array}$ & 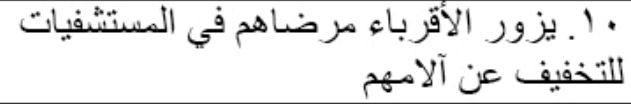 \\
\hline
\end{tabular}

